\title{
Indigenous Knowledge and Vocational Education: Marginalisation of Traditional Medicinal Treatments in Rwandan TVET Animal Health Courses
}

\section{Chika Ezeanya-Esiobu}

Senior Lecturer (Visiting), College of Business and Economics, University of Rwanda, Kigali

iD https://orcid.org/0000-0003-2244-0843

\section{Chidi Oguamanam}

Professor, Faculty of Law, University of Ottawa; Senior Fellow, Centre for International Governance Innovation (CIGI), Waterloo, Canada; Steering Committee Member and Researcher, Open African Innovation Research (Open AIR) network

(iD https://orcid.org/0000-0003-4301-9388

\section{Vedaste Ndungutse}

Lecturer, College of Agriculture, Animal Sciences and Veterinary Medicine, University of Rwanda, Musanze

iD https://orcid.org/0000-0002-9357-071X

\begin{abstract}
This study explores Rwandan ethno-veterinary knowledge and the degree to which this knowledge is reflected in the country's technical and vocational education and training (TVET) instruction. The knowledge considered is the Indigenous medicinal knowledge used by rural Rwandan livestock farmers to treat their cattle. Through interviews with farmers, TVET graduates and TVET teachers, and an examination of the current TVET Animal Health curriculum, the research identifies a neglect of Indigenous knowledge in the curriculum, despite the fact that local farmers use numerous Indigenous medicinal innovations to treat their animals. The focus of the Rwanda's TVET Animal Health curriculum is on Western-origin modern veterinary practices. The authors argue that this leaves Rwandan TVET Animal Health graduates unprepared for optimal engagement with rural farmers and with the full range of potential treatments.
\end{abstract}

\section{Keywords}

livestock farming, cattle, animal health, Indigenous knowledge, ethno-veterinary medicine, medicinal herbs, technical and vocational education and training (TVET), Rwanda 


\section{Acknowledgements}

This research was carried out under the auspices of the Open African Innovation Research (Open AIR) network, which is a partnership between the University of Cape Town, the University of Johannesburg, Strathmore University in Nairobi, the Nigerian Institute of Advanced Legal Studies, The American University in Cairo, and the University of Ottawa. The authors acknowledge the support provided for this research by Open AIR, the Social Sciences and Humanities Research Council of Canada, and the International Development Research Centre. The opinions expressed, as well as any errors, are entirely those of the authors. The authors also acknowledge the support provided by the University of Rwanda's College of Business and Economics and its College of Agriculture, Animal Sciences and Veterinary Medicine. The authors are thankful for the time and cooperation of all respondents, who patiently provided answers and guided the authors around research sites during the field visits, and for the dedicated research assistant work by University of Ottawa JD/MA student Jessica Hennings, who is a member of Open AIR's New and Emerging Researchers Group (NERG). This article draws on elements of a working paper (Ezeanya-Esiobu et al., 2020).

DOI: https://doi.org/10.23962/10539/31372

\section{Recommended citation}

Ezeanya-Esiobu, C., Oguamanam, C., \& Ndungutse, V. (2021). Indigenous knowledge and vocational education: Marginalisation of traditional medicinal treatments in Rwandan TVET Animal Health courses. The African Journal of Information and Communication (AJIC), 27, 1-23.

https://doi.org/10.23962/10539/31372

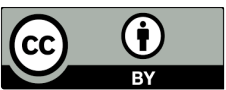

This article is licensed under a Creative Commons Attribution 4.0 International (CC BY 4.0) licence: https://creativecommons.org/licenses/by/4.0

\section{Introduction}

Often dismissed as fetish, retrogressive, superstitious, and of no scientific validity, Africa's Indigenous knowledge systems were mostly ridiculed by the colonial administrations. There was little critical consciousness of the implications of the imposition of an alien episteme on local communities possessing their own sophisticated Indigenous knowledge systems. The end of colonial rule in Sub-Saharan Africa did not generate a meaningful departure from reliance on Western knowledge systems, and the colonial state of affairs largely persists in many African countries in respect of the treatment of Indigenous knowledge in official, formal education curricula. Meanwhile, in other parts of the world—-for example, in China, India, and Japantremendous progress has been made in the recognition of traditional knowledge in 
the fields of governance, medicine, architecture, social organisation, technology, agriculture, and conflict resolution.

In this study, we explore Rwandan farmers' use of Indigenous knowledge to treat ailments in cattle, and the degree to which this ethno-veterinary medical knowledge is reflected in the country's technical and vocational education and training (TVET) instruction in Animal Health. Through interviews with farmers, TVET graduates and TVET teachers, and an examination of the current TVET Animal Health curriculum, the study identifies a stark contrast between the large body of Indigenous knowledge being used by Rwandan rural livestock farmers and the near-complete absence of representation of this knowledge in the country's TVET system.

\section{Research design}

Rwanda was judged to be an appropriate context for this case study because of its majority agrarian population and that population's centuries of Indigenous knowledge, particularly the agricultural and ethno-veterinary knowledge held and curated by traditional pastoral farmers. We conducted the study via qualitative means, with data collected in two forms: semi-structured interviews, guided by an interview protocol, with rural livestock farmers, TVET Animal Health teachers, and TVET graduates; and scrutiny of the curriculum content for the Rwandan TVET Animal Health qualifications (WDA, n.d.).

Eighteen interviews were conducted, with:

- $\quad$ six experienced livestock farmers (three female, three male), aged between 62 and 84, who had been keeping livestock for between 17 and 50 years;

- four less-experienced, younger livestock farmers (all male), aged between 27 and 34, who had been keeping livestock for between five and 10 years;

- three TVET Animal Health teachers (males), with teaching experience of two, three, and nine years, respectively, and two of whom were involved in TVET Animal Health curriculum development; and

- five TVET Animal Health graduates (males) now working in rural communities (three as veterinary pharmacists, two as veterinary clinicians), all in their positions for between three and six years.

The interviews were conducted in two locations:

- Mpenge cell, Muhoza sector, Musanze District, Northern Province; and

- Remera cell, Kiyumba sector, Muhanga District, Southern Province.

Purposive sampling was used to identify the farmers, TVET teachers, and TVET graduates interviewed in the two districts. The interview questionnaire was developed in English and translated into Kinyarwanda. The interviews were conducted in Kinyarwanda, and the responses were translated and transcribed into English for the data analysis. Each interview took about 30 minutes to complete. 


\section{Research context}

\section{Indigenous knowledge, education, colonialism, and African agriculture}

Our definition of Indigenous knowledge takes account of elements of definitions of Indigenous knowledge and its synonyms or constructs (such as, notably, traditional knowledge and local knowledge) in law (WIPO IGC, 2019) and in the extant literature (Oguamanam, 2006; Kiggundu, 2007; Bruchac, 2014). We use the term to reference multiple, open-ended, and complex sites of lived experiences through which non-Western Indigenous peoples and local communities engage with phenomena by way of language, practices, innovations, and ways of life, including stewardship (and co-stewardship with other life and non-life forces) for sustainable living; ecological and environmental cohesion; and spiritual, cultural, social, and economic harmony.

The theoretical underpinnings of Indigenous knowledge systems in general, and the place of Indigenous knowledge in education curriculum development, are still evolving. However, if education is generally accepted as a process through which individuals are able to acquire knowledge for specific goals that will be beneficial to themselves and society, then for education to successfully fulfil its objectives in any locale, an acknowledgement and incorporation of the pre-existing knowledge of its host community in curricula is needed. In several classic works on education, Dewey is specific about the place of community in successful learning. For Dewey, one of the aims of learning should be to work with communities in inculcating their banks of knowledge into younger generations (Dewey, 1959).

\section{Indigenous knowledge and education}

In the 1962 book The Structure of the Scientific Revolution, Kuhn opines that reference to "knowledge" as "universal" is in fact a reference to Western scientific knowledge, which, in turn, calls into question all other forms of knowledge and assumes that they are either irrelevant or sub-par (Kuhn, 1962). The idea that knowledge generated in the West should be wholly embraced by other regions is instrumental in the West's continued domination of the rest of the globe. So-called "Western culture", according to Oguamanam (2006, p. 19), is "a local tradition, which has been spread worldwide through intellectual colonization".

For a curriculum to produce learners who are aware of the opportunities and challenges within their immediate environment, its contents must reflect the real life and lived experiences of learners. White (1983) notes that no curriculum, educational programme, or policy should be analysed outside of its ideological, political, or environmental foundations. Educational curricula are inherently and directly connected to societal dynamics and power; therefore, whether intentionally or inadvertently, more emphasis is often placed on some knowledge form or system of knowledge over others. What is included, highlighted, downplayed, or excluded will grant or deny power to a segment of the population (White, 1983). In Pedagogy of the Oppressed, 
Freire maintains that it is critical that curricula in any educational setting are representative of "situations familiar to the individuals whose thematics are being examined, so that they can easily recognize the situations (and thus their own relation to them)" (Freire, 1968, p. 107). Educators who aim to produce learners who can create innovations grounded in Indigenous knowledge must focus attention on how their curriculum either affirms the knowledge forms, values, and ideals of the students' cultural milieu, or ignores, de-emphasises, and even ridicules it (McLaren, 2003). A core challenge then lies in integrating locally generated content, instructional strategies, and techniques in the curriculum design (Trifonas, 2003).

\section{Indigenous knorwledge, education, and colonialism}

Van Niekerk (2004) makes a case for the contextualisation of all curricula in order to reflect societal dynamics. Such contextualisation often requires the re-assessment of curricula, especially in formerly colonised territories (Danmole, 2011). According to UNESCO, "there is an urgent need to enhance the intergenerational transmission of indigenous knowledge, as a complement to mainstream education" (UNESCO, n.d.). Accordingly, UNESCO promotes efforts "to bring indigenous language and knowledge into school curricula and to move learning back into the community, thus reaffirming the status of elders as knowledge holders" (UNESCO, n.d.).

National education systems in most parts of Africa have their origins in colonialism. Curricula were copied verbatim from the education systems of colonial authorities, without thought being given to the Africans' cultural practices, Indigenous epistemologies, ontologies, and pedagogies. In the few instances where Africa's Indigenous knowledge found its way into colonial era curricula, it was often included in order to ridicule it, deride it, or cast it in a negative light, while holding up Western knowledge as the ideal. Empowerment, creativity, and innovation did not play a role in the design of academic programmes in colonial Africa (Freire, 1968; Nhalevilo, 2013; Owuor, 2007). Had they been considered, Africa's epistemologies would have been at the forefront, since their aim is to build confidence in learners and a sense of respect for their environments and lived realities.

The colonial governments' Victorian-era norms for male and female roles likewise influenced the structure of education in the colonised territories (Ezeanya-Esiobu, 2019). Despite the fact that across much of the continent, African women worked alongside their husbands, the colonisers established all-male schools and hired mostly men to work in government offices and establishments. For women, domestic management and training schools were established to orient them towards skills in, for example, "sewing, dressmaking, baking, cooking", decoration, and general home and housekeeping skills (Oguamanam, 2019, p. 16).

The end of colonial rule did not result in significant changes in curricula across much of Sub-Saharan Africa, since post-colonial governments remained dependent 
on the colonial authorities for education funding. Beyond that, many educated Africans whose task it was to educate the younger generation were beholden to the West and looked derogatorily upon Indigenous knowledge (Msila, 2016). For the most part, Western-based education continued to thrive across Africa, decades after the end of colonial rule (Gumbo, 2016). In a few instances of deviations from this norm, such as in Kenya, the government recognised the need to incorporate Indigenous knowledge into curricula. However, the government abandoned the idea due to the lack of manpower and technical know-how needed to adequately conceptualise and aggregate the Indigenous knowledge of the many ethnicities that make up that country (Owuor, 2007).

\section{African agriculture}

Across Africa, pastoralists have for generations successfully employed Indigenous medicinal knowledge in rearing livestock. Such ethno-veterinary medical knowledge abounds on the continent, especially in rural areas. However, practitioners of this knowledge are scarcely recognised. Much of the agricultural production in Africa happens at the smallholder level (Kamara et al., 2019). A report released by the Alliance for a Green Revolution in Africa (AGRA) concludes that smallholder farmers "will be vital to the continent's long-awaited green revolution" (AGRA, 2019). In terms of sustainability and conservation, smallholder farmers use predominantly natural or biodegradable pesticides, which are less toxic to the body and the environment than the conventional pesticides used in industrial agriculture (Barucha, 2019). Studies have established that "many of these small farmers are increasingly using innovative ways of reducing greenhouse gas emissions and adapting to climate change" (Barucha, 2019).

Goal 2 of the UN Sustainable Development Goals (SDGs) is the eradication of hunger. To achieve that goal, the UN targets an increase, of no less than $200 \%$, in agricultural productivity for smallholder farmers (UN, 2020). There is an expectation of an increase by the same percentage in the income of vulnerable populations who engage in smallholder agriculture, such as women, pastoralists, and fishing communities. A commitment to working with smallholder farmers inevitably places Indigenous knowledge of agriculture at the core of discussions of the SDGs (IISD, 2020). In a report, Realizing the Future We Want for All, the UN System Task Team on the Post-2015 UN Development Agenda noted the significance of Indigenous knowledge in the sustainability discourse, by observing that " $t$ ]raditional and indigenous knowledge, adaptation and coping strategies can be major assets for local response strategies" (UN, 2012, p. 28).

Indigenous knowledge of animal health is essentially an organic-friendly endeavour (Chander et al., 2011). Organic farming supports the use of local or native breeds since they are "less susceptible to stress and disease, and so the need for allopathic medicines and antibiotics is much lower." Therefore, "indigenous technical knowl- 
edge, available in poorer and developing countries, may provide an effective substitute for veterinary care" (Kumar et al., 2006, quoted in Chander et al., 2011, p. 977). According to a $2008 \mathrm{UN}$ report on a study that explored the relationship between organic agriculture and food security in Africa, the study findings "support the argument that organic agriculture can be more conducive to food security in Africa than most conventional production systems, and that it is more likely to be sustainable in the long term" (UNCTAD \& UNEP, 2008, p. iii).

\section{Rwandan livestock farming and Indigenous treatments}

Rwanda's livestock sector contributes roughly 16\% of the country's GDP (Mazimpaka, 2017). The Rwandan Government has initiated the Girinka (One Cow per Poor Family) Programme, promoting the rearing of cattle to increase wealth and productivity (USAID Rwanda, 2016). Cattle are integral to Rwandan culture, with the Inyambo breed traditionally used in royal ceremonies. It is an established practice to give a cow as a gesture of friendship and goodwill. Cows are also gifted as dowry, and can be offered as a sacrifice to the gods (Hirwa et al., 2017a). Due to the embeddedness of cattle in Rwandan culture, maintaining their health is a central aspect of Indigenous knowledge that is handed down from one generation to the next.

Cattle breeds reared in Rwanda can be divided into three categories: Indigenous, imported, and cross breeds. A study conducted in Nyagatare District, Eastern Province, found that $67.03 \%$ of cattle in the district were Indigenous breeds, $28.37 \%$ were cross breeds, and 4.6\% were imported breeds (Mazimpaka, 2017).

\section{Figure 1: Imported-breed cattle, Musanze District}

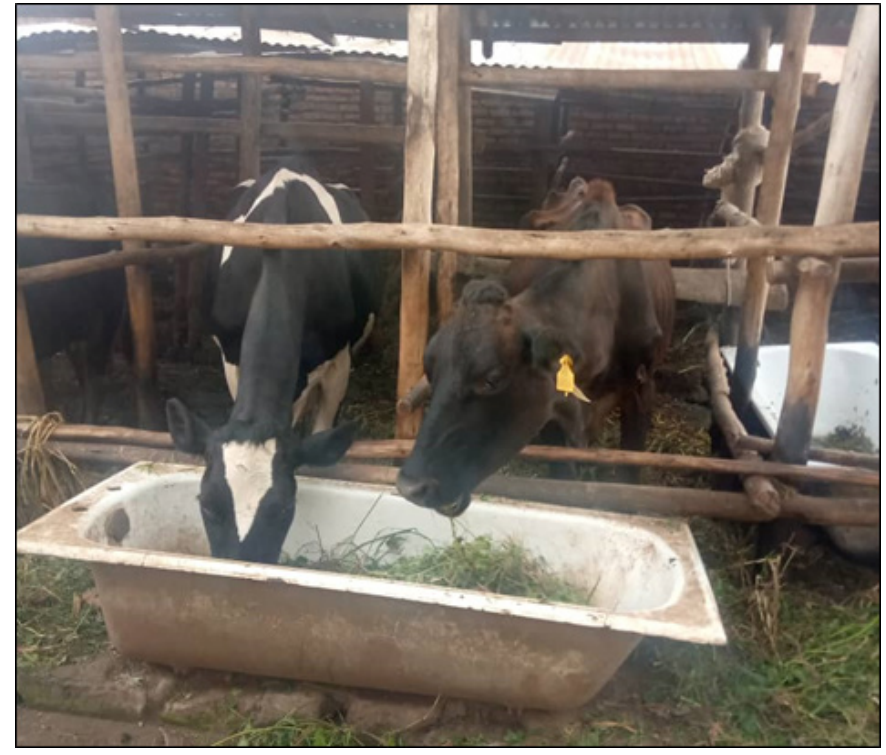

Photo source: Vedaste Ndungutse 
Imported breeds were introduced in Rwanda due to the low milk production of Indigenous breeds. However, these imported breeds are very susceptible to disease, and thus the government encourages cross-breeding between imported and local Indigenous breeds (Mazimpaka, 2017). The government also promotes the rearing of fully Indigenous breeds, due to their resilience to disease (Hirwa et al., 2017a). Indigenous cattle also have better heat tolerance, and adapt more easily to low quality food and limited quantity of feeds (Hirwa et al., 2017a). Indigenous breeds are also more resilient to tsetse flies, whose attack is often fatal for foreign breeds (Hirwa et al., 2017a; Mazimpaka, 2017).

Approximately $40 \%$ of cattle in Rwanda are fed via open grazing, with the rest fed via semi-grazing, which is a hybrid between open grazing and zero-grazing (where all feeds are transported to pens to feed animals) (USAID Rwanda, 2016). The Rwandan Government encourages zero-grazing, due to a shortage of land and in order to prevent the land degradation caused by open grazing (USAID Rwanda, 2016). Research conducted in Nyagatare District reported that $23.3 \%$ of cattle are being fed through zero-grazing (Mazimpaka, 2017).

More than 600 Rwandan Indigenous plant species are used as herbs in cosmetics, agriculture, food and beverage production, traditional medicine, and construction (Rwanda Environment Management Authority, 2019). In the areas surrounding Buhanga Forest in the Northern Province-specifically in Bikara Cell, Nkotsi Sector, Musanze District-around 45 herbs belonging to 28 families have been identified as useful in Indigenous medicine (Runyambo et al., 2016). In Buhanga Forest, six plant species have been identified that are traditionally used in treating cattle diseases, while another three species have been identified as being used for the traditional treatment of both cattle and human diseases (Runyambo et al., 2016).

Traditionally, Rwanda's pastoralists prepare medicine in the form of juice by pounding or crushing plant parts with wood or stone. Water is then typically used to dilute the juice (Runyambo et al., 2016). In Rwanda's Indigenous veterinary medical practice, medicine is administered through oral application $84 \%$ of the time, through external application on the skin $8 \%$ of the time, through the ears $5 \%$ of the time, and as an anal application 3\% of the time, depending on the infected part of the animal and the type of disease (Runyambo et al., 2016).

At the same time, veterinary doctors providing modern treatments are located all over the country, and thus most livestock holders in Rwanda, if they have the resources to pay for the service, have ready access to a veterinary doctor to take care of their sick animals.

The Government of Rwanda recognises the value of Indigenous knowledge. There is a public policy on traditional human medicine, and a forum of about 3,000 tra- 
ditional healers operating all over the country with government-sponsored training (Rwanda Environment Management Authority, 2019). Rwanda has signed the Nagoya $^{1}$ and Swakopmund ${ }^{2}$ Protocols and the International Treaty on Plant Genetic Resources for Food and Agriculture (ITPGRFA) for the use and protection of Indigenous knowledge, including farmers' practices (Rwanda Environment Management Authority, 2019).

\section{Rwandan TVET provision}

TVET was introduced in the Rwandan education system following a 2009 national audit that indicated a $60 \%$ shortage of skilled people in the country (Kiberu et al., 2009). The number of Vocational Training Centres (VTCs) grew from 61 in 2010 to 116 in 2012, resulting in a roughly 50\% increase in TVET enrolment (Ministry of Education, 2013). In 2013, for every 10 students attending TVET schools, eight were from rural areas, compared to 2005, when there were only four rural-origin students for every 10 TVET learners (Ministry of Education, 2013).

The policy establishing TVET is aligned with, among others, Rwanda's Science, Technology, and Innovation (STI) Policy and its National Employment Policy (Ministry of Education, 2008a). The training offered under TVET aims to respond to the labour market in the country and in the broader East African region (Ministry of Education, 2008b). In 2009, the government established the Workforce Development Authority (WDA), responsible for coordinating TVET via the identification of subjects to be taught; the development of curricula; the training of teachers; the provision of examinations; and the certification, accreditation, regulation, and inspection of TVET institutions (Ministry of Education, 2013).

In its curriculum development work, the WDA considers the labour market needs of the private sector and potential employers, who are included in curriculum development meetings. Emphasis is placed on hands-on skills, with more hours allocated to practical activities than to theoretical learning. In order to be part of the TVET curriculum development process, a TVET teacher must possess knowledge and skills in the subject matter being developed; knowledge and skills in information and communication technologies (ICTs); and a minimum of three years of teaching experience built around learner-centred, competence-based curricula.

\section{Findings on livestock farmers' use of Indigenous treatments}

Of the six experienced livestock farmers interviewed, most stated that they learned livestock farming from their parents, with one specifying that he also acquired knowledge from other livestock farmers. All four of the younger, less-experienced

1 Nagoya Protocol on Access to Genetic Resources and the Fair and Equitable Sharing of Benefits Arising from their Utilization to the Convention on Biological Diversity.

2 Swakopmund Protocol on the Protection of Traditional Knowledge and Expressions of Folklore. 
livestock farmers interviewed said they learned livestock farming from their parents and grandparents.

When asked if they have used traditional cures to treat sick animals, all six of the experienced farmers, and three of the four less-experienced farmers, said they have done so, and gave numerous examples (Table 1). The experienced farmers were found to have far more knowledge of the Indigenous treatments than the younger farmers.

Table 1: Indigenous treatments of cattle, as identified by farmer interviewees

\begin{tabular}{|c|c|c|}
\hline Ailment & Symptoms & Treatments, and medicinal substances used \\
\hline $\begin{array}{l}\text { rutandara, } \\
\text { or intan- } \\
\text { dara }\end{array}$ & $\begin{array}{l}\text { retention of fluids } \\
\text { in the mouth of } \\
\text { the cow } \\
\text { increased } \\
\text { temperature, } \\
\text { unstable limbs, } \\
\text { immobility, } \\
\text { refusal to graze }\end{array}$ & $\begin{array}{l}\text { A blood vessel located on the neck of the cow is cut and } \\
\text { allowed to bleed (a process known as irago in Kinyarwanda). } \\
\text { Leaves of traditional Colocasia are pounded, mixed with } \\
\text { water, and administered orally to the animal. } \\
\text { The Tetradenia riparia (Umuravumba) plant is administered } \\
\text { orally (dosage depends on the animal's age). } \\
\text { The Umusange (Entada abyssinica) plant is mixed with a } \\
\text { Colocasia plant called Iteke and administered orally. } \\
\text { The animal is beaten using Acanthus pubescens (Amatovu), a } \\
\text { plant with thorns (a remedy known to be especially effective } \\
\text { and allowing for speedy recovery of the sick animal). }\end{array}$ \\
\hline $\begin{array}{l}\text { Ikibagari- } \\
\text { ra, or } \\
\text { inka igira } \\
\text { umuriro } \\
\text { mwinshi }\end{array}$ & $\begin{array}{l}\text { fever caused by } \\
\text { ticks }\end{array}$ & $\begin{array}{l}\text { - The Ikibomrwe plant is administered orally to the animal (a } \\
\text { remedy said to not be very effective, with many cows dying } \\
\text { even after receiving the treatment). } \\
\text { A hot knife is used to burn the Ganglion cysts, caused by } \\
\text { fever, under the ears. }\end{array}$ \\
\hline gufuma & $\begin{array}{l}\text { retained placenta: } \\
\text { inability to release } \\
\text { placenta and } \\
\text { afterbirth from } \\
\text { the uterus after } \\
\text { delivery }\end{array}$ & $\begin{array}{l}\text { One of these two treatments is implemented to induce release if a } \\
\text { cow's placenta and afterbirth are not released within six hours of } \\
\text { giving birth (if not treated, a retained placenta can cause com- } \\
\text { plications, include heavy bleeding and infection, which can be } \\
\text { detrimental): } \\
\text { - The Phyllanthus nummulariifolius (Umuhanurankuba) or } \\
\text { Umuboko (Phytolacca dodecandra) plant is pounded, mixed } \\
\text { with water, and administered orally. } \\
\text { The Umuyobora and Umubogora herbs are pounded, mixed } \\
\text { with water, and administered orally. } \\
\text { As a preventive measure, animals are given the pounded leaves of } \\
\text { Umuhoko or Ikawa mixed in water orally, minutes after delivery, in } \\
\text { order to speed up the process of placenta and afterbirth discharge. }\end{array}$ \\
\hline
\end{tabular}




\begin{tabular}{|c|c|c|}
\hline Akanyaga & $\begin{array}{l}\text { general body pain, } \\
\text { lethargy, loss of } \\
\text { hair on skin }\end{array}$ & $\begin{array}{l}\text { Approximately } 3 \text { to } 4 \text { litres of blood are bled from the cow } \\
\text { via the process known as irago (see treatment of rutandara } \\
\text { above). Then animal hair is used to stop the bleeding, while } \\
\text { umwumano (milk from a cow in gestation) is poured over the } \\
\text { hair to bind the hair to the incision. } \\
\text { Another treatment, mentioned by a single farmer among the } \\
\text { experienced male farmers, is to collect human bodily fluids, } \\
\text { after sexual intercourse, on a towel, and then rub the fluids } \\
\text { on the body of the animal (in order to prevent the disease } \\
\text { from progressing to the hair-loss stage). }\end{array}$ \\
\hline $\begin{array}{l}\text { Urubiga or } \\
\text { amashyuyo }\end{array}$ & $\begin{array}{l}\text { fever, causing } \\
\text { disruption of } \\
\text { feeding and loss } \\
\text { of weight }\end{array}$ & $\begin{array}{l}\text { The cow is bled via the irago process (see treatment of } \\
\text { rutandara above), and then taken to a place where there is } \\
\text { plentiful feed and encouraged to eat to its satisfaction. }\end{array}$ \\
\hline Ibyashi & $\begin{array}{l}\text { fungal infection } \\
\text { between the } \\
\text { hooves }\end{array}$ & $\begin{array}{l}\text { - Faecal matter of a hen in incubation (amatoto y'inkoko irariye) } \\
\text { is rubbed on the infected area. } \\
\text { - Cow butter (amavutay'inka) is heated and melted on the } \\
\text { infected area. } \\
\text { Black "charcoal" from a disused radio battery is rubbed on } \\
\text { the infected area. }\end{array}$ \\
\hline Ifumbi & $\begin{array}{l}\text { mastitis: pus and } \\
\text { blood coming } \\
\text { from teats }\end{array}$ & $\begin{array}{l}\text { - The herbs Mitragyne rubrostipulosa (Umuzibaziba), } \\
\text { Umunkamba, Umukuzanyana, Umutanga, and n' imizi } \\
\text { y'umutarishonga are administered orally. }\end{array}$ \\
\hline Ubutaka & $\begin{array}{l}\text { fever, difficulty in } \\
\text { breathing }\end{array}$ & $\begin{array}{l}\text { The Umusange and Magaru herbs, and a banana species } \\
\text { called Intokatoki, are mixed together and administered } \\
\text { orally. (During the treatment, the cow is not provided with } \\
\text { bedding, i.e., is not given organic materials such as straw and } \\
\text { sawdust usually put in the pen to support the animal when } \\
\text { at rest.) }\end{array}$ \\
\hline impiswi & diarrhoea & $\begin{array}{l}\text { - The Umubati, Umuzingangore and Idoma herbs (and } \\
\text { sometimes also the Umunaba plant) are administered orally. } \\
\text { Englerina schubotziana/solanaceae/solanum sp (Umutobotobo } \\
\text { utagiraamabwa) (without the thorns) is administered orally. }\end{array}$ \\
\hline $\begin{array}{l}\text { Amata } \\
\text { acika }\end{array}$ & $\begin{array}{l}\text { production of } \\
\text { sedimented, non- } \\
\text { homogenised } \\
\text { milk }\end{array}$ & $\begin{array}{l}\text { - The Magaru, Umureterezaho, Umuzigangore herbs, and } \\
\text { Englerina schubotziana/solanaceae/solanum sp (Umutobotobo } \\
\text { utagiraamabwa) (without the thorns) are administered orally. }\end{array}$ \\
\hline Inkubasi & $\begin{array}{l}\text { increased } \\
\text { temperature in } \\
\text { feet and legs, } \\
\text { with liquids } \\
\text { dripping from the } \\
\text { mouth and nose } \\
\text { (usually occurs in } \\
\text { early months of } \\
\text { gestation) }\end{array}$ & - Umusange herbs are administered orally. \\
\hline Umuzimire & blood in faeces & - Umuzigangore herbs are administered orally. \\
\hline
\end{tabular}


Figure 2: Cow treated for mastitis

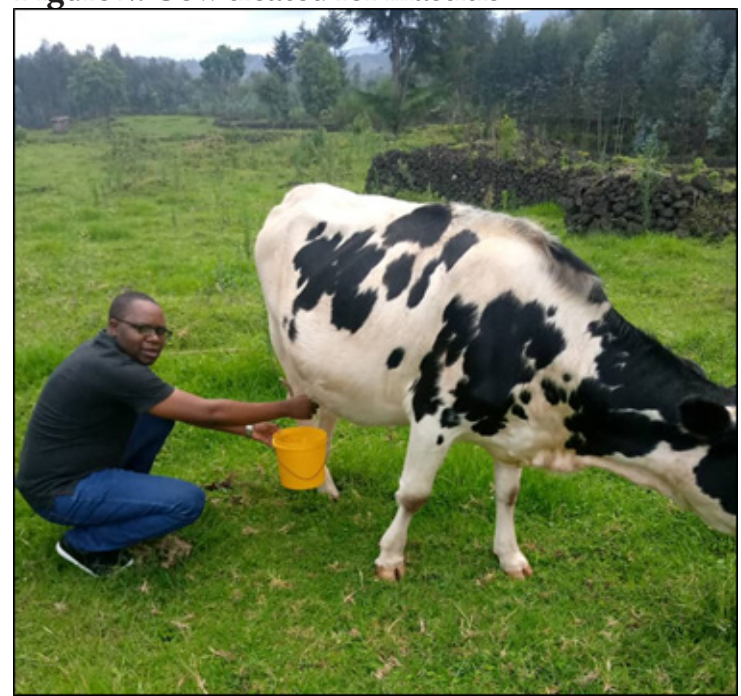

Researcher with cow that has been cured of ifumbi (mastitis) with medicinal herbs, Musanze District Photo source: Vedaste Ndungutse

All the farmers, both experienced and less-experienced, unanimously agreed that Indigenous treatments are still effective for animal disease treatment. Another farmer indicated that he is no longer using Indigenous methods to treat his animals because, in his experience, the necessary herbs have become difficult to find. One farmer, who presently keeps only imported cows (also called "exotic" cows by farmers), pointed out that Indigenous medicine tends to be practised mostly on Indigenous cows, especially in rural areas. However, at the same time, he confirmed that for diseases such as rutandara and akanyaga, he still uses traditional methods, even for his imported cows.

All the farmers were of the view that remedies based on Indigenous knowledge are much more cost-effective than their Western counterparts. Despite the availability of government subsidies and generous livestock insurance programmes, many of the farmers still find the cost of Western-method treatments for their cattle to be beyond their means. In the words of one respondent farmer:

Modern medicine is very expensive. [The] traditional one is cheaper, and with 2,000 Rwandan francs [approx. USD2.20], an animal can be treated with Indigenous methods since plants used are obtained locally.

According to another farmer:

Modern medicine is very effective. Animals are treated after consultation to be sure of the disease to be treated. However, it is very expensive. Indigenous medicine is cheaper. In some cases, you offer one bottle of local banana wine to a traditional healer after he has healed the animal. 
All respondent farmers were generally of the view that modern veterinary medicine is superior in most respects to Indigenous medicine. There was consensus that modern veterinary medicine excels in diagnoses and in the precise prescription of a remedy to treat identified disease, while traditional veterinary medicine lacks this kind of diagnostic precision. With Indigenous treatments, the dosage regimes and treatment strategies are not precise. Sometimes several different herbs are given to the animals without knowing exactly which one is most effective. The lack of precision can sometimes result in animal fatalities.

The respondents identified some modern veterinary medicinal remedies or practices for which there are no Indigenous alternatives or equivalents, including the procedures of artificial insemination and Caesarean section. At the same time, one farmer pointed out that some diseases, such as akanyaga and rutandara, are best treated with Indigenous medicine. This farmer did, however, agree that some ailments are more efficiently treated with modern medicine, citing the example of ikibagarira:

Traditionally, we did not know the cause of ikibagarira. It was in 1980 that we were trained on its cause, where they told us that it is caused by ticks. Since then, modern medicine has been used mostly in the treatment of ikibagarira very well.

It is widely felt that foreign-breed cows should be treated using only modern medicine, while Indigenous cattle (and cross breeds) can be treated using both Indigenous and modern remedies. One of the interviewees noted that fewer and fewer farmers are using Indigenous treatments - in part because of the many new diseases that have come to Rwanda with the introduction of foreign cattle breeds. Another reason given for the decline in the use of Indigenous treatment methods is the government mandate that a veterinary doctor is to be called whenever a cow is sick.

One farmer was of the view that Indigenous and modern medicines are complementary, although he added that modern medicine is superior. Some of the farmers reported that for most ailments suffered by their livestock, they first commence treatment using Indigenous treatment methods, with a veterinary doctor sought only when traditional cures fail or where no traditional cure is known.

\section{Findings on TVET Animal Health instruction}

\section{Curriculum content}

In our review of the curriculum documents for Rwanda's TVET Animal Health certificate and diploma programmes, we found that there is no Indigenous knowledge content (WDA, n.d.). The curricula could easily be applicable to any European or North American country. And although Kinyarwanda is the language most easily understood by many TVET students and teachers, none of the curriculum content is in Kinyarwanda. There is no indication that students serviced by the curriculum are 
going to apply their trades in locations where longstanding Indigenous knowledge and Indigenous animal health practices are present. There is, in fact, no mention of the Rwandan context in the curriculum.

\section{Farmers'views}

Most of the farmers interviewed were found to be in favour of the idea of incorporating Indigenous knowledge into the TVET Animal Health curriculum. The most prevalent view was that the TVET courses should teach students how to use local herbs in treating animal diseases and how to effectively combine them with modern veterinary medicine. There was also a widely held view that including Indigenous knowledge in the curriculum would allow useful animal health Indigenous knowledge to spread all over the country, rather than being, in some cases, localised within districts.

Only two farmers had opinions that diverged strongly from the others. One believed that including Indigenous knowledge in the TVET curriculum should be for the purpose of cultural preservation only, and that students should be taught to conduct all treatments using modern medicine. The other was of the opinion that modern medicine had effectively replaced its Indigenous counterpart, and that, accordingly, teaching Indigenous knowledge at TVET schools would amount to teaching "backwardness". Thus, in his view, there is no need to include Indigenous knowledge in the TVET Animal Health curriculum.

\section{Graduates'views}

All five of the TVET Animal Health graduates interviewed said they are aware of the value that traditional livestock farmers attach to Indigenous animal health treatments. They also confirmed that they were not taught any form of Indigenous animal health knowledge during their TVET studies. Four of the five graduates interviewed did not consider the curriculum's exclusion of Indigenous knowledge to be problematic. According to one of these four respondents, "it is not necessary to add Indigenous knowledge in TVET curriculum. We have veterinary doctors who are trained, and their knowledge is enough." According to another of the four respondents not concerned with the absence of Indigenous knowledge in the curriculum, "modern medicine is more trustable, and we advise livestock farmers to use it rather than [the] Indigenous one".

In the view of these four respondents, such knowledge is only fit to be passed on orally from generation to generation, since it is "archaic" and was only used prior to the advent of modern veterinary medicine. One of the four expressed his conviction that, by every standard, modern veterinary medicine is superior to Indigenous medicine, and that any contrary belief is only upheld in some rural areas: "[These] few remote areas are behind in development. Therefore, the adoption of modern vet medicine is slow." Another stated that livestock farmers often try to convince him that Indige- 
nous knowledge is superior to modern knowledge in the treatment of certain diseases, but his response is always to advise them to rely only on modern medicine. One of the four was of the view that Indigenous treatments can have severe side-effects, especially for foreign breeds that do not tolerate traditional medicine, and can even lead to livestock death.

The one respondent with a differing perspective was of the view that Indigenous medicine is as important as modern medicine, because in many cases animals can be treated and healed through its application. Thus, in this respondent's opinion, teaching Indigenous ethno-veterinary knowledge in TVET schools is necessary to equip students with all the available skills required for livestock management.

All five of the TVET graduates interviewed listed the disadvantages of Indigenous animal medicine when compared to Western approaches, including the concern that, with Indigenous medicine, inaccurate diagnoses result in high rates of fatality, and the concern that there is a lack of standardisation of dosages. With modern veterinary health care, they pointed out, diagnosis is much more precise, and the administration of medicine follows scientifically established dosages. One graduate now working as a vet practitioner observed that-unfortunately, in his view-the low cost of Indigenous medicine, compared to paying for the services of trained vets, has a countervailing effect on the patronage of animal clinics and formal veterinary medical practices.

\section{Teachers'views}

All three TVET Animal Health teachers interviewed were aware of the existence and use of Indigenous knowledge in animal health in Rwanda. However, they all said that they consider modern medicine to be far more efficacious than Indigenous medicine, on the grounds that livestock farmers who use Indigenous cures also need modern medicine, while others use only modern cures and do not need Indigenous medicine.

Two of the teachers said they have never incorporated Indigenous knowledge into their teaching or encouraged its discussion in class. According to one,

Indigenous knowledge is allowed [as] it is a localised knowledge. It varies from one area to another. There is no regulation restricting people to teach it. Myself, I do not teach Indigenous knowledge because I do not know it. I only teach modern medicine.

The second teacher who does not incorporate Indigenous knowledge into his teaching said he believes that teaching such knowledge is not appropriate, and not allowed in the classroom, since it is not relevant, as "TVET is about teaching students modern medicine which is up to date." According to these two teachers, the TVET 
students are not interested in Indigenous knowledge, as they come to school to learn about modern medicine.

Figure 3: TVET Animal Health teacher

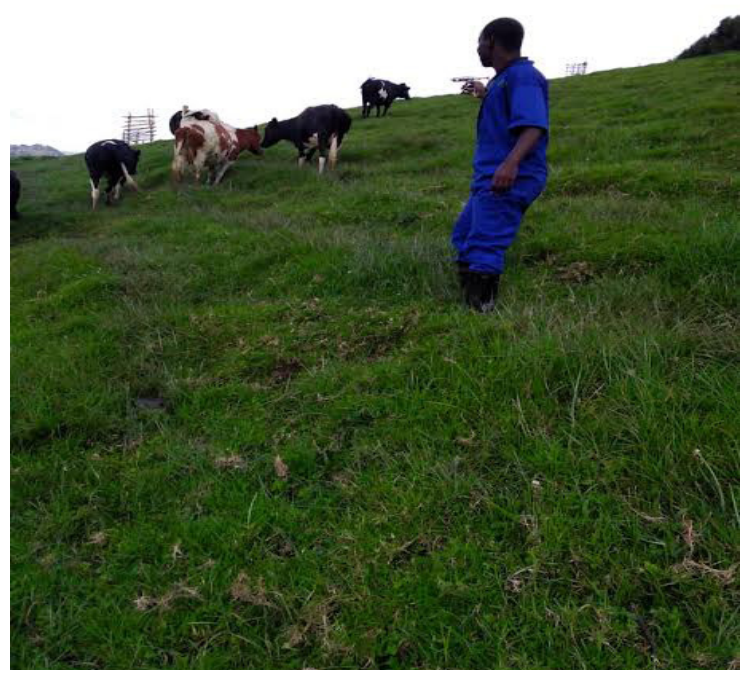

TVET teacher with grazing cattle, Muhanga District

Photo source: Vedaste Ndunguste

The third teacher interviewed, however, was of the view that Rwanda's Indigenous ethno-veterinary knowledge can assist TVET Animal Health students when they graduate and go into the field. This is so, he said, because in his understanding some ailments are treatable only by Indigenous methods, with no available treatment in modern veterinary medicine. He added that, given the percentage of Indigenous cattle in Rwanda, it is important to ensure that Indigenous knowledge of animal husbandry is not marginalised. If incorporated into the TVET Animal Health curriculum, Indigenous treatments would complement modern medicine. The teacher also stated that, even though it is not part of the curriculum, he sometimes includes Indigenous knowledge in his teaching. For instance, he sometimes references the practice of treating animals with charcoal, the practice of treating animals with cow butter (amavutay'inka), and the process known as kwina, in which Indigenous medicine is administered to the animal anally through a piece of local bamboo straw, usually as a treatment for constipation. He does this because, in his view, many students are interested in knowing about Indigenous treatments.

The two teachers who had participated in developing the TVET Animal Health curriculum confirmed that Rwanda's Indigenous knowledge is not considered during curriculum development. One of the two said this lack of inclusion of Indigenous 
practices contrasted with government support for Indigenous knowledge in other sectors. He pointed to the example of the certification given by the government, through the Ministry of Health, to Indigenous knowledge practitioners of human medicine.

\section{Analysis, conclusions and recommendations}

It is clear in the findings of this study that Indigenous knowledge of cattle treatments is both held and used by rural livestock farmers in Rwanda and, at the same time, that such knowledge is not being supported by the country's TVET Animal Health curriculum. The livestock farmers interviewed hold nuanced views about the interfaces between Indigenous and modern Western treatments for their cattle. The farmers, both experienced and less-experienced, know about the Indigenous techniques, and all but one of the farmers has used them on their cattle, either directly or with the assistance of traditional animal health practitioners. A key advantage of Indigenous medicine cited by the farmers is its cost-effectiveness, with the use of modern treatments, via modern veterinary clinics, being prohibitively expensive and thus only used as a last resort or for ailments not treatable using traditional means. The farmers do, at the same time, acknowledge the greater precision and predictability of modern veterinary treatments, and the greater efficacy of modern treatments for foreign breeds of cattle (with Indigenous breeds and cross breeds seen as compatible with effective treatment by both Indigenous and modern methods).

Meanwhile, in TVET Animal Health education, the Indigenous medicinal knowledge known and practised by rural livestock farmers is not provided for in any meaningful way. The TVET Animal Health curriculum covers none of the Indigenous knowledge detailed by the farmers in the research interviews. Moreover, four of the five TVET Animal Health graduates interviewed, and two of the three TVET Animal Health teachers interviewed, see absolutely no value in making Indigenous animal health treatments part of TVET instruction - and even the one graduate and one teacher who see some value in making TVET learners aware of such knowledge do not see the need for it to be part of the formal curriculum. The TVET graduates, who in their work as vets and animal pharmacists interact with rural livestock farmers, are not equipped with the knowledge necessary to optimally interact with these farmers.

To be relevant to the continent's overall advancement, Africa's education curricula need to incorporate the continent's Indigenous knowledge and practices across numerous fields and sectors (Msila, 2016). In the planning and development of curricula, knowledge that is Indigenous to learners' locales must be infused generously, with the aim of such knowledge being appropriate human-centred development. As seen in the passage quoted earlier in this article from UNESCO, there is global recognition among education policymakers of the "urgent need to enhance the 
intergenerational transmission of indigenous knowledge" and "to bring indigenous language and knowledge into school curricula" (UNESCO, n.d.).

Rwandan policymakers need to pursue several elements if they wish to build Indigenous knowledge into the country's TVET Animal Health curriculum. At the foundation is a need for research into Rwandan Indigenous animal health knowledge, and the widespread dissemination of these research findings. Research is also needed into ways of improving Indigenous animal health practices in Rwanda, as the farmer respondents noted that lack of precision in dosages, and uncertainty about which herbs work for which disease, hinder the effectiveness of Indigenous treatments. Western medicine, which many respondents in this study consider to be much more efficacious, is itself evolutionary, refined through centuries of research and development in order to attain the legitimacy and trust currently ascribed to it. Accordingly, there is a need to prioritise the establishment of research laboratories dedicated to indigenous Rwandan animal health by the nation's Ministry of Education, and specifically the Ministry's Directorate for Science, Technology and Research (DSTR).

Another important element is teacher training. Before the TVET Animal Health curriculum can be transformed, teachers must be educated about using Indigenous knowledge for Africa's advancement. Such training can be located within the larger UN SDGs framework, with appreciation of Indigenous knowledge presented as a prerequisite for sustainable development. That exercise should aim to foster appreciation of cultural diversity across all sectors, not only agriculture.

Another crucial element is the preservation and expansion of Rwanda's biodiversity. As noted by one of the farmer interviewees in this study, some of the herbs used to effectively treat certain diseases in animals are no longer available in abundance. One way in which Rwandan biodiversity relevant to Indigenous animal health care could be preserved is through the creation of herbal nurseries at TVET schools, where efforts could be made to cultivate known local herbs that are used in, inter alia, animal health maintenance. Such herbaria or farms could be maintained by TVET students and teachers, in cooperation with community-based Indigenous knowledge practitioners.

\section{References}

Ademola, I. O., \& Eloff, J. N. (2011). Anthelmintic activity of acetone extract and fractions of Vernonia amygdalina against Haemonchus contortus eggs and larvae. Tropical Animal Health Production, 43(2), 521-527.

https://doi.org/10.1007/s11250-010-9727-7

Alliance for a Green Revolution in Africa (AGRA). (2019). The bidden middle: A quiet revolution in the private sector driving agricultural transformation. Africa Agriculture Status Report 2019. https://agra.org/wp-content/uploads/2019/09/AASR2019The-Hidden-Middleweb.pdf 
Barucha, Z. P. (2019, February 20). How small farms are leading the way towards sustainable agriculture. Independent. https://www.independent.co.uk/news/science/smallfarms-sustainable-agriculture-climate-change-africa-farming-a8786216.html

Blaustein, R. J. (2008). The Green Revolution arrives in Africa. BioScience, 58(1), 8-14. https://doi.org/10.1641/B580103

Bruchac, M. (2014). Indigenous knowledge and traditional knowledge. In C. Smith (Ed.), Encyclopedia of global archaeology (pp. 3814-3824). Springer.

https://doi.org/10.1007/978-1-4419-0465-2_10

Byavu, N., Henrard, C., Dubois, M., \& Malaisse, F. (2000). Phytothérapie traditionnelle des bovins dans les élevages de la plaine de la Ruzizi. Biotechnology, Agronomy, Society and Environment, 4(3), 135-156. https://www.researchgate.net/publication/26392451_ Phytotherapie traditionnelle des bovins dans les elevages de la plaine de la $\underline{\text { Ruzizi }}$

Chander, M., Subrahmanyeswari, B., Mukherjee, R., \& Kumar, S. (2011). Organic livestock production: An emerging opportunity with new challenges for producers in tropical countries. Revue scientifique et technique, 30(3), 969-983. https://doi.org/10.20506/rst.30.3.2092

Colin, S. (2011). Fundamentals of animal science (1st ed.). Delman Cengage Learning.

Cronje, A., Beer, J., \& Ankiewicz, P. (2015). The development and use of an instrument to investigate science teachers' views on indigenous knowledge. African Journal of Research in Mathematics, Science and Technology Education, 19(3), 319-332. https://doi.org/10.1080/10288457.2015.1108567

Danmole, B. T. (2011). Emerging issues on the universal basic education curriculum in Nigeria: Implications for the science and technology component. Pakistan Journal of Social Sciences, 8, 62-68. https://doi.org/10.3923/pjssci.2011.62.68

Dewey, J. (1959). Moral principles and education. Philosophical Library.

Ezeanya-Esiobu, C. (2019). Indigenous knowledge and education in Africa. Springer Nature. https://doi.org/10.1007/978-981-13-6635-2

Ezeanya-Esiobu, C., Oguamanam, C., \& Ndungutse, V. (2020). Marginalisation of Indigenous knowledge in African education: The case of Rwandan traditional medicinal treatments for livestock. Open AIR Working Paper 24. Open African Innovation Research (Open AIR).

Freire, P. (1968). Pedagogy of the oppressed. Penguin Books.

Gumbo, M. T. (2016). A model for indigenising the university curriculum: A quest for educational relevance. In V. Msila, \& M.T. Gumbo (Eds.), Africanising the curriculum: Indigenous perspectives and theories (pp. 121-139). Sun Press.

Hamburger, M., \& Hostettmann, K. (1991). Bioactivity in plants: The link between phytochemistry and medicine. Phytochemistry, 30, 3864-3874.

https://doi.org/10.1016/0031-9422(91)83425-K

Hirwa, C. D. A., Kugonza, D. R., Murekezi, T., Rwemarika, J. D., Kayitesi, A., Musemakweri, A., Shabayiro, J. P., Shumbusho, F., Manzi, M., \& Safari, T. (2017a). Management and phenotypic features of indigenous cattle in Rwanda. International Journal of Livestock Production, 8(7), 95-112. https://doi.org/10.5897/IJLP2017.0362 
Hirwa, C. D. A., Ebong, C., Mutabazi, J., Mutimura, M., Nyirishema, F., \& Wallace, P. A. (2017b). Livestock farming and management: The case of meat production and processing in Rwanda. Asian Journal of Animal Sciences, 11, 96-107. https://doi.org/10.3923/ajas.2017.96.107

International Institute for Sustainable Development (IISD). (2020, February 20). UN agencies explore farm-to-fork policy frameworks to achieve SDGs 1, 2. https://sdg. iisd.org/news/un-agencies-explore-farm-to-fork-policy-frameworks-to-achievesdgs-1-2/

Kabera, J., Tuyisenge, R., Ugirinshuti, V., Nyirabageni, A., \& Munyabuhoro, S. (2014). Preliminary investigation on anthelmintic activity and phytochemical screening of leaf crude extracts of Tithonia diversifolia and Tephrosia vogelii. African Journal of Microbiology Research, 8(25), 2449-2457. https://doi.org/10.5897/AJMR2013.6525

Kamara, A., Conteh, A., Rhodes, E. R., \& Cooke, R. A. (2019). The relevance of smallholder farming to African agricultural growth and development. African Journal of Food, Agriculture, Nutrition and Development, 19(1), 14043-14065. https://doi.org/10.18697/AJFAND.84.BLFB1010

Kiberu, B., Kabatesi, L., Karinda, P., \& Mugabi, S. (2009). Labour market information system-WDA: Situation of 4 pilot TVET institutions in Rwanda. https://docplayer. net/23695677-Labour-market-information-system-wda.html

Kiggundu, J. (2007). Intellectual property law and the protection of indigenous knowledge. In I. Mazonde, \& P. Thomas (Eds.), Indigenous knowledge systems and intellectual property in the Twenty-First Century: Perspectives from Southern Africa (pp. 26-47). CODESRIA.

Kloppenburg Jr, J. (1998). First the seed: The political economy of plant biotechnology. University of Wisconsin Press.

Kuhn, T. (1962). The structure of scientific revolutions. University of Chicago Press.

Mawere, M. (2015). Indigenous knowledge and public education in Sub-Saharan Africa. Africa Spectrum, 50(2), 57-71. https://doi.org/10.1177/000203971505000203

Mazimpaka, E. (2017). Characterization of cattle production systems in Nyagatare District of Eastern Province, Rwanda. Rheology: Open Access, 1(2), 1-21. https://www. omicsonline.org/open-access/characterization-of-cattle-production-systems-innyagatare-district-ofeastern-province-rwanda.php?aid=91895

Mbanzamihigo, L., Dethie, F., Kabera, N. J., Ugirinshuti, V., \& Nyirabageni, A. (2013). Evaluation of the effectiveness of two medicinal plants Vernonia amygdalina and Leonotis nepetaefolia on the gastrointestinal parasites of goats in Rwanda: Case study of Huye and Gisagara districts. Journal of Veterinary Medicine and Animal Health, 5(8), 229-236.

McLaren, P. (2003). Critical pedagogy: A look at the major concepts. In A. Darder, M. Baltodano, \& R. D. Torres (Eds.), The critical pedagogy reader (pp. 69-96). RoutledgeFalmer.

Memmi, A. (1965). The colonizer and the colonized. Beacon Press.

Ministry for Agriculture and Animal Resources (MINAGRI). (2000). Strategic Plan for the Transformation of Agriculture in Rwanda - Phase II (PSTA II). https://rwanda. countrystat.org/fileadmin/user upload/countrystat fenix/congo/docs/PSTA IIphp.pdf 
Ministry of Education (2008a). Rwanda Education Sector Strategic Plan 2008-2012. https:// planipolis.iiep.unesco.org/sites/planipolis/files/ressources/rwanda essp 20082012.pdf

Ministry of Education (2008b). Technical and Vocational Education and Training (TVET) Policy in Rwanda. https://planipolis.iiep.unesco.org/sites/planipolis/files/ ressources/rwanda technical vocational education policy.pdf

Ministry of Education (2013). Education strategic plan 2013/14-2017/18. https://www. mineduc.gov.rw/fileadmin/user_upload/Education_Sector_Strategic_Plan_2013_2018.pdf

Ministry of Education, Science, Technology and Scientific Research. (2003). Rwanda National Curriculum Development Centre 6 year plan: 2003 to 2008. https://planipolis. iiep.unesco.org/sites/planipolis/files/ressources/rwanda curriculum reform plan march 2003.pdf

Msila, V. (2016). Africanisation of education and the search for relevance and context. In V. Msila, \& M. Gumbo (Eds.), Africanising the curriculum: Indigenous perspectives and theories (pp. 57-69). Sun Press. https://doi.org/10.18820/9780992236083

Muhizi, T., Sinumvayo, J. P., Nkurunziza, J. B., Grelier, S., \& Coma, V. (2011). Antibacterial activity assessment of different crude extracts obtained from the leaves of Caesalpinia decapitala grown in Rwanda. Rwanda Journal, 24, 7-14. https://www.ajol.info/index. $\mathrm{php} / \mathrm{rj} /$ issue/view/9026

Muthee, D., Kilemba, G., \& Masinde, J. (2019). The role of indigenous knowledge systems in enhancing agricultural productivity in Kenya. Eastern Africa Journal of Contemporary Research, 1(1), 34-35. https://www.researchgate.net/publication/332408330 The Role of Indigenous Knowledge Systems in Enhancing Agricultural Productivity in Kenya Article information For Authors

Mwadime, R. K. (1999). Indigenous knowledge systems for an alternative culture in science: The role of nutritionists in Africa. In L. M. Semali, \& L. K. Joe (Eds.), What is indigenous knowledge? Voices from the academy (pp. 243-267). Falmer Press.

Nhalevilo, E. Z. F. A. (2013). Rethinking the history of inclusion of IKS in school curricula: Endeavoring to legitimate the subject. International Journal of Science and Math Education, 11, 23-42. https://doi.org/10.1007/S10763-012-9382-8

Njoroge, G. N., \& Bussmann, R. W. (2006). Herbal usage and informant consensus in ethnoveterinary management of cattle diseases among the Kikuyus (Central Kenya). Journal of Ethnopharmacology, 108(3), 332-339. https://doi.org/10.1016/j.jep.2006.05.031

Nshimiyimana, J., \& Mutandwa, E. (2010). Seasonal dynamics and distribution of ticks in Rwanda: Implications for tick control strategy in Rwanda. International Journal of Animal and Veterinary Advances, 2(1), 21-25. https://maxwellsci.com/print/ijava/v221-25.pdf

Nyamanga, P. A., Suda, C., \& Aagaard-Hansen, J. (2008). The socio-cultural context and practical implications of ethnoveterinary medical pluralism in Western Kenya. Agriculture and Human Values, 25(4), 513-527. https://doi.org/10.1007/s10460-008-9141-1 
Oguamanam, C. (2006). International law and indigenous knowledge: Intellectual property, plant biodiversity, and traditional medicine. University of Toronto Press. https://doi.org/10.3138/9781442676244

Oguamanam, C. (2008). Local knowledge as trapped knowledge: Intellectual property, culture, power and politics. The Journal of World Intellectual Property, 11(1), 29-57. https://doi.org/10.1111/j.1747-1796.2008.00333.x

Oguamanam, C. (2019). A benchmark on the bench. Esquire Publications.

Owuor, J. (2007). Integrating African indigenous knowledge in Kenya's formal education system: The potential for sustainable development. Journal of Contemporary Issues in Education, 2(2), 21-37. https://doi.org/10.20355/C5Z594

Paul, J. A. \& Wahlberg, K. (2008). A new era of world hunger? The global food crisis analyzed. Friedrich Ebert Stiftung and Global Policy Forum.

Rugg, H. O. (Ed.). (1927). The foundations of curriculum-making: Twenty-sixth yearbook of the National Society for the Study of Education (Part II). Public School Publishing.

Runyambo, I., Minani, V., Bizuru, E., Nyirambangutse, B., Nsengimana, J. S., \& Ndimukaga, M. (2016). Assessment of traditional ecological knowledge and beliefs in the utilization of important plant species: The case of Buhanga Sacred Forest, Rwanda. Koedoe: African Protected Area Conservation and Science, 58(1), 1-11.

https://doi.org/10.4102/koedoe.v58i1.1348

Rwanda Environment Management Authority. (2019). Guideline and Toolkit for Access and Benefit Sharing of Traditional Knowledge Associated with Genetic Resources in Rwanda: Information for Providers, Users, and Regulatory Institutions.

Srikantaiah, D. (2005). Education: Building on indigenous knowledge. Indigenous Knowledge (IK) Notes, No. 87. World Bank. https://openknowledge.worldbank.org/ handle/10986/10747

Swee, K. Y., Wan, Y. H., Boon, K. B., Woon, S. L., Huynh, K., \& Noorjahan, B. A. (2010). Vernonia amygdalina, an ethnoveterinary and ethnomedical used green vegetable with multiple bioactivities. Journal of Medical Plants Research, 4(25), 2787-2812. https://doi.org/10.5897/JMPR.9001288

Touqeer, S., Saeed, M. A. \& Ajaib, A. (2013). A review on the phytochemistry and pharmacology of genus Tephrosia. Phytopharmacology, 4(3), 598-637. http:// inforesights.com/phytopharmacology/files/pp4v3i4.pdf

Trifonas, P. (2003). Toward a decolonizing pedagogy: Social justice reconsidered. In P. Trifonas (Ed.), Rethinking education for social change. Routledge.

UN. (2012). Realizing the future we want for all: Report to the Secretary-General. UN System Task Team on the Post-2015 UN Development Agenda. https://www.un.org/ millenniumgoals/pdf/Post 2015 UNTTreport.pdf

UN. (2020). The sustainable development goals report 2020. https://unstats.un.org/sdgs/ report/2020/\#sdg-goals

UNCTAD, \& UNEP. (2008). Organic agriculture and food security in Africa. https://unctad. org/system/files/official-document/ditcted200715 en.pdf

UNESCO. (n.d.). Indigenous knowledge and knowledge transmission: Revitalising knowledge - Indigenous education. https://en.unesco.org/links/transmission 
USAID Rwanda. (2016). Feed the future innovation lab for livestock systems Rwanda: Animal source foods production and marketing brief. Livestock Lab. https://livestocklab.ifas. ufl.edu/media/livestocklabifasufledu/pdf-/pdfs-by-country-pre2019/Rwanda Brief ASFProdMkt final.pdf

Van Niekerk, L. (2004). Distance education as a function of community. South African Journal of Higher Education, 18(3), 185-195. https://doi.org/10.4314/sajhe.v18i3.25490

Warren, D. (1991). Using indigenous knowledge in agricultural development. World Bank.

Waweru, W. W., Osuwat, L. O., \& Wambugu, F. K. (2017). Medicinal plants used in Rwanda. Journal of Pharmacognosy and Phytochemistry, 6(1), 322-324.

White, D. (1983). After the divided curriculum. The Victorian Teacher, 7.

Williams, D. L., \& Muchena, O. N. (1991). Utilizing indigenous knowledge systems in agricultural education to promote sustainable agriculture. Journal of Agricultural Education, 32(4), 52-57. https://doi.org/10.5032/jae.1991.04052

WIPO IGC (2019, April 9). The protection of traditional knowledge: Draft articles. WIPO/ GRTKF/IC/40/4Rev 2, 22 March 2019. WIPO Intergovernmental Committee on Intellectual Property and Genetic Resources, Traditional Knowledge and Folklore (IGC). https://www.wipo.int/meetings/en/doc details.jsp?doc $\mathrm{id}=433260$

Workplace Development Authority (WDA). (n.d.). Sector: Agriculture and food processing: Animal health. https://mis.rp.ac.rw/curriculum/3/41

World Health Organisation (WHO). (2020). Traditional, contemporary, and integrative medicine. $\quad$ https://www.who.int/health-topics/traditional-complementary-andintegrative-medicine\#tab=tab 